\title{
Learner's English Language Attitude In Madura: Raising Awareness Of The Notion Of Global English
}

\author{
Maulana Yusuf Aditya \\ STKIP PGRI Bangkalan, Madura, Indonesia \\ Maulanayusufaditya@gmail.com
}

\begin{abstract}
A central issue of this paper is to study the attitude of learners toward English language. It also highlights the teachers' approach and methodology in teaching English and points out that it is necessary to raise learner's awareness towards English language. This paper tries to find why so many learners do not like to study English by comparing the attitudes of the learners who like English and those who do not and by reviewing their comments in the questionnaire. This paper also studies the sociolinguistics factors that responsible for their attitude toward English language. A Likert scale questionnaire was administered to collect data from 112 the first year high school students in Bangkalan, Madura. Results show that students do not like to learn English because they think English is difficult to be mastered and they learn English just as an obligation for academic purposes. Furthermore, it is necessary to ease students' mind from making mistakes by raising their awareness that English is widely used by nonnative speakers in Asia, Europe or Africa and native English is not the only variety that is spoken in the world.
\end{abstract}

Keywords: Language Learner, Language Learning,

Languge Attitude, Perception, and Awareness.

\section{INTRODUCTION}

Language is the primary means of human communication. It is a powerful social force that does more than convey intended referential information. It also indicates both personal and social characteristics of the speaker. Depending on the particular listener, a speaker's accent, speech patterns, vocabulary, intonation etc. can serve as markers for evaluating that speaker's appearance, personality, social status and character, among other things. (Melander, 2003)

English is recognized as the lingua franca for communication across nations and cultures, and is the most desired second or foreign language in most countries in the world. English is used as a second or foreign language in the workplace, international trade, global media, education, tourism, business, and technology.There is a great amount of research on attitudes towards different languages (Marley 2004; Balcazar, 2003; Malallah 2000), towards different varieties of English and other languages (Karstadt, 2002; Zhou 2002; Assaf 2001). Different aspects of language attitudes have also been studied such as the relation between attitudes and motivation (Donitsa-Schmidt et al. 2004, Bernaus et al. 2004), and the relationship between attitudes and level of achievement (Graham 2004).

In Madura, the students study English just for an obligation. Some of them does not realize that English is very important subject in the future. That is why the writer try to measure language attitude and to raise students' awareness toward English.

\section{METHODS}

This study was part of larger research project on Madurese-speaking English student's language, identity, and educational development. The project was descriptive qualitative. This study examined issues of learner's language attitudes toward English by using direct method. A Likert scale questionnaire was administered to collect data from 112 the first year high school students in Bangkalan, Madura. The following number of students were randomly selected for the survey:

\begin{tabular}{ccc}
\hline NO & School & Number of Students \\
\hline 1 & SMAN 3 Bangkalan & 40 \\
\hline 2 & SMA As-Shomadiyah & 35 \\
\hline 3 & SMA Al-Hidayah & 37 \\
\hline & Total & 112 \\
\hline
\end{tabular}

\section{RESULT AND DISCUSSION}

After administering the questionnaire, the survey showed that the majority of students think English is necessary for traveling, entertainment such a music or movies and using modern gadget like smartphones and computers. It also pointed out that there is a contradiction between students' understanding towards the importance of English and their attitudes towards English, they wish they had more competence, but they do not like English subject in school.

Table 1. Do you like learning English subject?

\begin{tabular}{llll}
$\mathrm{a}=$ yes & $\mathrm{b}=$ no & \\
\cline { 1 - 4 } & $\mathrm{a}=$ Group A & $\mathrm{b}=$ Group B & Total \\
\hline & 42 & 70 & 112 \\
\hline Students & $37,5 \%$ & $62,5 \%$ & $100 \%$ \\
\hline
\end{tabular}

As shown in table 1, 42 students $(37,5 \%)$ answered that they like learning English (group A) and 70 students $(62,5 \%)$ answered that they do not like learning English (group B). It means that they have negative attitudes toward English learning in school. 
Table 2. You are now learning English to:

$\mathrm{a}=$ earn good score $\quad \mathrm{b}=$ speak with native speaker of

English $\mathrm{c}=$ travel

$\mathrm{d}=$ go to bachelor degree $\mathrm{e}=$ because everybody does $\mathrm{f}=$ do not know

\begin{tabular}{cccccccc}
\hline & $\mathrm{a}$ & $\mathrm{b}$ & $\mathrm{c}$ & $\mathrm{d}$ & $\mathrm{e}$ & $\mathrm{f}$ & Total \\
\hline Group & 11 & 15 & 7 & 9 & 0 & 0 & 42 \\
A & $15 \%$ & $36 \%$ & $17 \%$ & $21 \%$ & $0 \%$ & $0 \%$ & $100 \%$ \\
$\%$ & $26 \%$ & & & & \\
Group & 42 & 8 & 11 & 1 & 5 & 3 & 70 \\
B & $60 \%$ & $11 \%$ & $16 \%$ & $2 \%$ & $7 \%$ & $4 \%$ & $100 \%$ \\
$\%$ & & & & & & & \\
\hline
\end{tabular}

To find out why many students do not like learning English, students in group A and group B are compared in relation to the questionnaire items that seem to show their positive or negative attitudes toward English. Table 2 shows students' purposes on learning English at the present. It tells that $26 \%$ of group A students are learning English to earn good score, whereas $60 \%$ of group B students think so. It is necessary to realize that such large portion of students is learning English just for the good score. Those who are interested in learning English, on the other side, are motivated by communicative purposes rather than academic purposes.

Table 3. In your experience of English learning at school you were motivated by:

$\mathrm{a}=$ exams $\quad \mathrm{b}=$ teachers $\mathrm{c}=$ textbooks $\mathrm{d}=$ to do the same as everyone else

$\mathrm{e}=$ possibility of communication with native speakers or others $\mathrm{f}=$ other

\begin{tabular}{cccccccc}
\hline & $\mathrm{a}$ & $\mathrm{b}$ & $\mathrm{c}$ & $\mathrm{d}$ & $\mathrm{e}$ & $\mathrm{f}$ & Total \\
\hline Group A & 20 & 7 & 5 & 0 & 10 & 0 & 42 \\
$\%$ & $47 \%$ & $17 \%$ & $12 \%$ & $0 \%$ & $24 \%$ & $0 \%$ & $100 \%$ \\
Group B & 56 & 4 & 3 & 0 & 5 & 2 & 70 \\
$\%$ & $80 \%$ & $6 \%$ & $4 \%$ & $0 \%$ & $7 \%$ & $3 \%$ & $100 \%$ \\
\hline
\end{tabular}

As shown in table 3 , it is clear that examination is the strongest motivation for both groups but more so for group B (80\%) than group A $(47 \%)$. The next strongest motivation is possibility of communication with native speakers or others, group A $(24 \%)$ and group B (7\%). In other words, the table 3 shows that examinations make students to learn English, but it cannot make them to be interested in learning English.

Table 4. Do you want to make friends with foreigners? $\mathrm{a}=$ yes

\begin{tabular}{llll}
\multicolumn{2}{c}{$b=$ no } & & \\
\hline & $\mathrm{a}$ & $\mathrm{b}$ & Total \\
\hline Group A & 39 & 3 & 42 \\
$\%$ & $93 \%$ & $7 \%$ & $100 \%$ \\
Group B & 49 & 21 & 70 \\
$\%$ & $70 \%$ & $30 \%$ & $100 \%$ \\
\hline
\end{tabular}

Table 2 shows that about half of the students are motivated to learn English just for good score. Table 6 shows that students of group A are more interested in making friends with foreigners than students of group B. But it still shows that both groups are interested in making friends with foreigners rather than avoiding them.

Table 5. Can you notice when English is not standard British or US English?

$\mathrm{a}=$ yes

\begin{tabular}{cccc}
$\mathrm{b}=$ no & & & \\
\hline & $\mathrm{a}$ & $\mathrm{b}$ & Total \\
\hline Group A & 3 & 39 & 42 \\
$\%$ & $7 \%$ & $93 \%$ & $100 \%$ \\
Group B & 2 & 68 & 70 \\
$\%$ & $3 \%$ & $97 \%$ & $100 \%$
\end{tabular}

$93 \%$ of group A students and $97 \%$ of group B students say that they cannot determine standard British/US English from other varieties as shown in table 5. For communicative purposes, therefor, it seems more important to focus on fluency rather than accuracy especially in oral communication at low levels. If accuracy is stressed too much as it had been done in the past, students lose interest in using the target language because they are affraid of making mistakes or being corrected by the teachers.

Table 6. Frankly speaking, English is not necessary in my life.

$\mathrm{a}=$ strongly agree
$\mathrm{d}=$ strongly disagree

Table 6 shows that $37 \%$ of group B students think that English is unnecessary in their lives while only $5 \%$ of group A students think so. If students think that the subject that they is studying will not be useful in the future, it is not likely that they will study it hard. A few group B students, however, comment that they felt happy when they were able to understand some parts of English songs or movies, or when they were able to communicate with foreigners in English. it is therefor important to appreciate such positive attitudes of the students and try to find ways to encourage them to experience such felings more often. It would be necessary to give the students various programs according to their needs. Those who plan to continue their study to university would need academic reading, for instance, whereas students who are more interested in using English for travelling or fun would like to study basic oral conversational and listening skill.

\section{Students' Comment}

Four questions were asked for the students to answer freely in writing at the end of the questionnaire. Among the positive comments about English, they say they were happy when they could understand part of English lyrics from popular songs or movies. There are also comments that English is needed in the future. Majority of students say that they would like to study conversation with 
naitve speaker and learn English through popular song or movies.

On the other hand, some students explain that they do not like to learn English mainly because it is difficult. They also say that learning English in Madura is not for communicating in English but learning for examinations.

\section{Discussion: Raising Students' Awareness}

By comparing several differences in the attitudes of group A and B students, and observing a brief description of students' written comments, it is understood how students feel about English, what can English teachers do to improve students' competence in English. In order to improve this situation, it is not only necessary to consider what technique can be employed to improve their English skill, but also to think of ways to motivate students and make enjoyable classroom condition in teaching English.

Teaching materials and models may depend on a standard or native English, but the outcome may not be as perfect as the model and some characteristics of learner's language and culture will influence the output variety of the learner. If the students become aware that it is natural that their variety of English is different from a model that is based on one of the native varieties of English, the learning process will not be as painful as it has been. As their learning proceeds, more accuracy may be required according to the situation in which English is used. However, it will still be different from any native varieties of English.

Furthermore, English is considered important because most TV channels, books, music, movies and instructions use this language. The findings agree with Sadanand (1993) that the attitudes towards the use of different languages are motivated by the speaker's perception of the role of each language and the functions it performs in relation to each other. The findings in line with Coulmas (1997) who stated that people choose languages which suit their various needs and purposes.

\section{CONCLUSION}

To summarize the above discussion, the survey shows that about two thirds of group A and B students do not like to learn English because they think English is difficult to be mastered and they learn English just as an obligation to academic purposes. Concurrently, some students are interested in speaking with foreigners and they do not have any hostile feelings against English or English speaking countries. In order to fix up such situations, teachers should make an enjoyable environment for learning English. Furthermore, it is necessary to ease students' mind from making mistakes by raising their awareness that
English is widely used by non-native speakers in Asia, Europe or Africa and native English is not the only variety that is spoken in the world.

\section{ACKNOWLEDGEMENT}

The Author is deeply indebted to the three high school English teachers and their students for their permission to conduct the research in their classes.

\section{REFERENCES}

Assaf, A. S. (2001). Palestinian students' attitudes towards Modern Standard Arabic and Palestinian City Arabic. RELC Journal, 32, 2, 45-62.

Balcazar, C. (2003). Language Shift and Language Attitudes of Kaqchikel Maya Adolescents. Arizona State University.

Bernaus, M., Masgoret, A. M., Gardner, R. C., \& Reyes, E (2004). Motivation and Attitudes Towards Learning Languages in Multicultural Classrooms. The International Journal of Multilingualism, 1, 2, 75-89.

Coulmas, F. (1997). The handbook of sociolinguistics. Oxford, UK: Blackwell.

Donitsa-Schmidt., Inbar, S. O., \& Shohamy, E. (2004). The Effects of Teaching Spoken Arabic on Students' Attitudes and Motivation in Israel. The Modern Language Journal, 88, ii, 217-228.

Graham, S. J. (2004). Giving up on Modern Foreign Languages? Students' Perceptions of Learning French. The Modern Language Journal, 88, 171-191.

Karstadt, A. (2002). Standard Englishes: What Do American Undergraduates Think? English Today, 18,3, 38-45.

Malallah, S. (2000) . English in an Arabic Environment: Current Attitudes to English Among Kuwait University Students. International Journal of Bilingual Education and Bilingualism, 3, 1, 19-43.

Marley, D. (2004). Language Attitudes in Moroco Following Recent Changes in Language Policy. Language Policy, 3, 25-46.

Melander, L. (2003). Language Attitudes Evaluational Reactions to Spoken Language. Hogskolan Dalarna.

Sadanand, K. (1993). Assesing Attitudes to English and Language Use. Indian Journal of Applied Linguistics, XIX (1), 123-139.

Zhou, M. (2002). The Spread of Putonghua and Language Attitude Changes in Shanghai and Guangzhou China. Journal of Asian Pacific Communication, 11, 2, 23125 